\title{
Prototipe Sistem Smart Trash Berbasis IOT (Internet Of Things) dengan Aplikasi Android
}

\author{
Ali Wafi ${ }^{1}$, Herry Setyawan', Sofia Ariyani ${ }^{1}$ \\ ${ }^{1}$ Teknik Elektro, Fakultas Teknik, Universitas Muhammadiyah Jember \\ Jl. Karimata No. 49 Jember 68121 \\ E-mail: Wafi7086@gmail.com
}

\begin{abstract}
ABSTRAK
Abstrak - Tata kelola sampah yang kurang baik dan kurangnya kesadaran masyarakat terhadap kebersihan lingkungan terutama membuang sampah pada tempatnya menyebabkan sampah menumpuk dan mengeluarkan bau busuk yang dapat menjadi sumber penularan penyakit. Kurangnya teknologi informasi pengelolaan sampah oleh petugas kebersihan menyebabkan penanganan sampah menjadi lambat. Berdasarkan permasalahan tersebut maka perlu adanya tempat sampah otomatis pemilah sampah organik dan anorganik agar sesuai dengan jenis tempat sampahnya serta menambahkan fungsi IOT(Internet Of Things) yang dapat memberikan informasi lebih awal bahwa tempat sampah telah penuh untuk diproses dengan cepat. Prototipe tempat sampah pintar menggunakan mikrokontroler ESP 32 sebagai kontrol sistem. Sensor proximity induktif dan kapasitif untuk mendeteksi jenis sampah organik atau anorganik. Servo untuk mengendalikan pintu tempat sampah dan memilah sampah. Sensor ultrasonik untuk mendeteksi keberadaan manusia dan ketinggian sampah. Hasil dari pembuatan alat didapatkan keberhasilan deteksi sampah organik 95\%, deteksi sampah anorganik 97,5\%, sensor jarak buka tutup 99,26\%, sensor jarak organik 99,07\%, sensor jarak anorganik 99,21\% dan dapat mengirimkan hasil monitoring secara real time serta notifikasi ke aplikasi android sebagai pemberitahuan jika tempat sampah telah penuh.
\end{abstract}

Kata kunci: Tata kelola sampah, Sampah organik dan anorganik, Mikrokontroler ESP 32, Internet Of Things

Copyright @ 2019 Universitas Muhammadiyah Jember.

\section{PENDAHULUAN}

Masalah sampah menjadi masalah yang tidak bisa dihindari dan terus berkembang. Jika dibiarkan akan berdampak pada lingkungan yang menjadi kotor dan tidak sehat. Tata kelola sampah yang kurang baik menyebabkan sampah menumpuk dan mengeluarkan bau busuk serta dapat menjadi sumber penularan penyakit. Sampah juga bisa mengakibatkan penyumbatan pada saluran drainase dan sungai. Masih kurangnya kesadaran dan kepedulian masyarakat terhadap kebersihan lingkungan menyebabkan permasalahan sampah masih menjadi persoalan serius bagi pemerintah. Kurangnya teknologi informasi pengelolaan sampah oleh petugas kebersihan menyebabkan penanganan sampah menjadi lambat. Informasi tentang kondisi volume tempat sampah dapat membantu mencegah menumpuknya sampah dan penularan penyakit. Maka dari itu, di butuhkan alat deteksi dan peringatan dini tentang kondisi volume tempat sampah yang dapat mengirimkan informasi bahwa tempat sampah sudah penuh untuk segera diproses dengan cepat.

Penelitian ini bertujuan untuk membuat smart trash bin berbasis Arduino Uno menggunakan sensor HC-SR04 sebagai pendeteksi jarak untuk mengetahui volume sampah pada tempat sampah, untuk pemberitahuan bahwa tempat sampah telah penuh menggunakan buzzer dan led sebagai indikator. Dari hasil pengujian perangkat Smart Trash Bin diperoleh kesimpulan bahwa sensor HC-SR04 dapat mengetahui volume sampah berdasarkan alur program yang dimasukkan ke dalam mikrokontroler Arduino [1]. Pada penelitian sebelumnya, yaitu merancang sebuah tempat sampah pintar berbasis Arduino Uno menggunakan sensor HCSRF04 sebagai pendeteksi ketinggian sampah dan buka tutup tempat sampah secara otomatis, indikator bahwa tempat sampah telah penuh menggunakan led dan buzzer. Dari hasil pengujian perangkat diperoleh kesimpulan bahwa sensor HCSRF04 dapat mengetahui volume sampah berdasarkan alur program yang dimasukkan ke dalam mikrokontroler Arduino Uno R3 [2]. Dari hasil kajian permasalahan tentang pengelolaan sampah yang telah saya amati, maka dalam penelitian ini dikembangkan tentang pengelolaan sampah yang dapat memilah sampah organik dan anorganik serta dapat mengirimkan informasi kondisi tempat sampah. Dengan menambahkan fungsi IOT (Internet Of Things) yang dapat memberikan informasi tentang keadaan tempat sampah yang sudah penuh kepada 
petugas kebersihan berbasis android. Sehingga lebih efisien dalam pengelolaan sampah karena tidak perlu menunggu laporan dari masyarakat.

Tujuan dari penelitian ini yaitu membuat sistem otomatisasi tempat sampah yang dapat memberikan pemberitahuan apabila tempat sampah telah penuh dengan menggunakan mikrokontroler ESP 32 yang akan terintegrasi dengan sensor ultrasonik, tempat sampah dapat memilah antara sampah organik dan anorganik dan pihak yang dituju dapat menerima pemberitahuan dengan baik bahwa tempat sampah telah penuh. Manfaat dari penelitian ini adalah menciptakan lingkungan yang bersih dari sampah yang menumpuk dengan tersedianya tempat sampah pintar yang dapat memberikan informasi kepada petugas kebersihan agar sampah segera diambil untuk mencegah sampah terlalu lama menumpuk sehingga menimbulkan bau yang tidak sedap dan menjadi sumber penyakit serta memberikan kemudahan kepada pihak petugas kebersihan dalam melakukan pemeriksaan dan mengambil sampah ketika telah penuh.

\section{KAJIAN PUSTAKA DAN PENGEMBANGAN HIPOTESIS}

Beberapa Penelitian sebelumnya, seperti perancangan smart trash bin berbasis Arduino Uno dilengkapi dengan sensor HCSR04 untuk mendeteksi volume sampah, sedangkan indikator menggunakan led dan buzzer. Kelebihan dari penelitian sebelumnya adalah biaya perancangan murah, tidak bergantung pada koneksi internet sehingga dapat ditempatkan pada daerah terpencil, dan kelemahannya adalah petugas menunggu laporan masyarakat jika tempat sampah penuh. Berikutnya adalah perancangan tempat sampah pintar berbasis Arduino Uno dilengkapi dengan sensor HCSRF04 untuk mendeteksi volume sampah, sedangkan indikator menggunakan sirine. Kelebihan dari penelitian tersebut adalah biaya perancangan murah, tidak bergantung pada koneksi internet sehingga dapat ditempatkan pada daerah terpencil, sedangkan kelemahannya adalah petugas menunggu laporan masyarakat jika tempat sampah telah penuh. Maka pada penelitian ini dilakukan perancangan smart trash berbasis Internet Of Things supaya kondisi tempat sampah dapat termonitoring oleh petugas dan dapat mengetahui tempat sampah telah penuh melalui notifikasi.

\subsection{Mikrokontroler ESP 32}

Mikrokontroler ESP merupakan penerus dari mikrokontroler ESP8266. Mikrokontroler ESP 32 sudah terdapat modul Wi-Fi sehingga mendukung untuk pembuatan sistem aplikasi berbasis Internet of Things. Pin pada mikrokontroler ESP 32 memiliki fungsi analog dan digital.

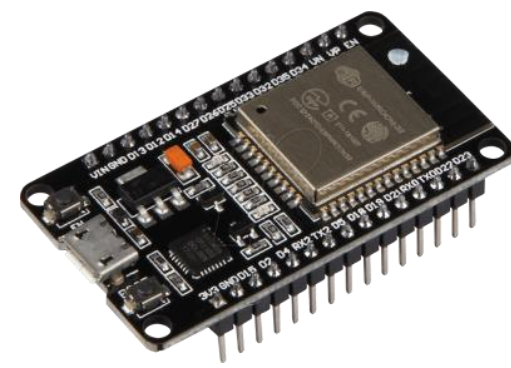

Gambar 1. Mikrokontroler ESP 32 (Sumber: Suhaeb, Sutarsi. 2017 )

\subsection{Sensor Ultrasonik}

Sensor ultrasonik adalah sensor jarak yang bekerja berdasarkan pantulan gelombang suara yang dikeluarkan kemudian pantulan suara yang diterima diproses untuk mengetahui jarak antara sensor dengan objek. Pada sensor ultrasonik, terdapat piezoelectric yang berguna membangkitkan gelombang ultrasonik.

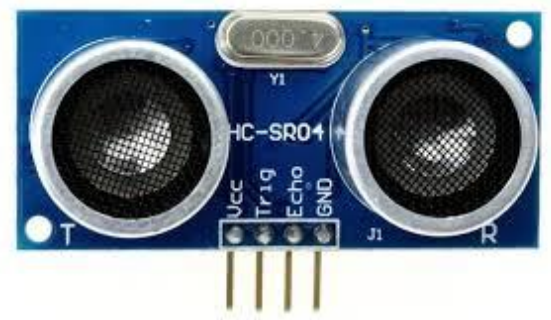

Gambar 2. Sensor Ultrasonik

(Sumber: Pratama, Hadijaya. 2012) 


\subsection{Motor Servo}

Motor servo adalah tipe motor yang dirancang dengan sistem kontrol umpan balik loop tertutup, sehingga posisi sudut poros motor dapat diatur. Motor servo terdiri atas potensiometer, motor DC dan serangkaian gear.

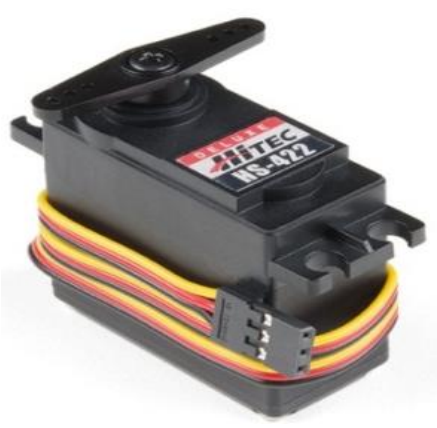

Gambar 3. Motor Servo

(Sumber: Wuryanto, Anus. 2019)

\subsection{Sensor Proximity Kapasitif}

Sensor kapasitif merupakan sensor yang dapat mendeteksi bahan logam dan non logam dan bekerja berdasarkan konsep kapasitif. Jarak jangkauan deteksi dari sensor yaitu sejauh $5 \mathrm{~mm}$. Proses pembacaan objek dipengaruhi oleh luas permukaan benda, jarak dan jenis bahan benda.

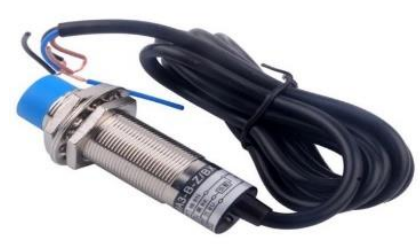

Gambar 4. Sensor Proximity Kapasitif (Sumber: Sukarjadi. 2017)

\subsection{Sensor Proximity Induktif}

Sensor induktif adalah tipe sensor jarak yang dapat digunakan untuk mendeteksi logam atau metal. Sensor proximity induktif tingkat sensitivitas sangat tinggi. Jarak jangkau pembacaan $1 \mathrm{~mm}$. proses pembacaan objek dipengaruhi oleh permukaan benda dan jarak.

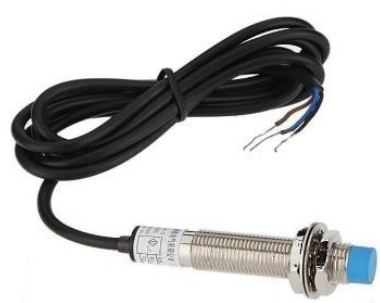

Gambar 5. Sensor Proximity Induktif (Sumber: Sukarjadi. 2017)

\section{METODE PENELITIAN}

Pada penelitian ini menggunakan empat tahap proses yaitu perumusan masalah, analisa kebutuhan, perancangan alat, dan pengujian alat.

\subsection{Diagram Blok}

Berikut merupakan blok diagram dengan sistem kerja yaitu tutup tempat sampah akan membuka secara otomatis ketika sensor ultrasonik mendeteksi manusia $<30 \mathrm{~cm}$ kemudian sampah akan dipilah oleh sensor proximity kapasitif dan induktif. Ketinggian sampah akan di monitoring melalui aplikasi android dan akan mengirimkan notifikasi ketika tempat sampah telah penuh. 


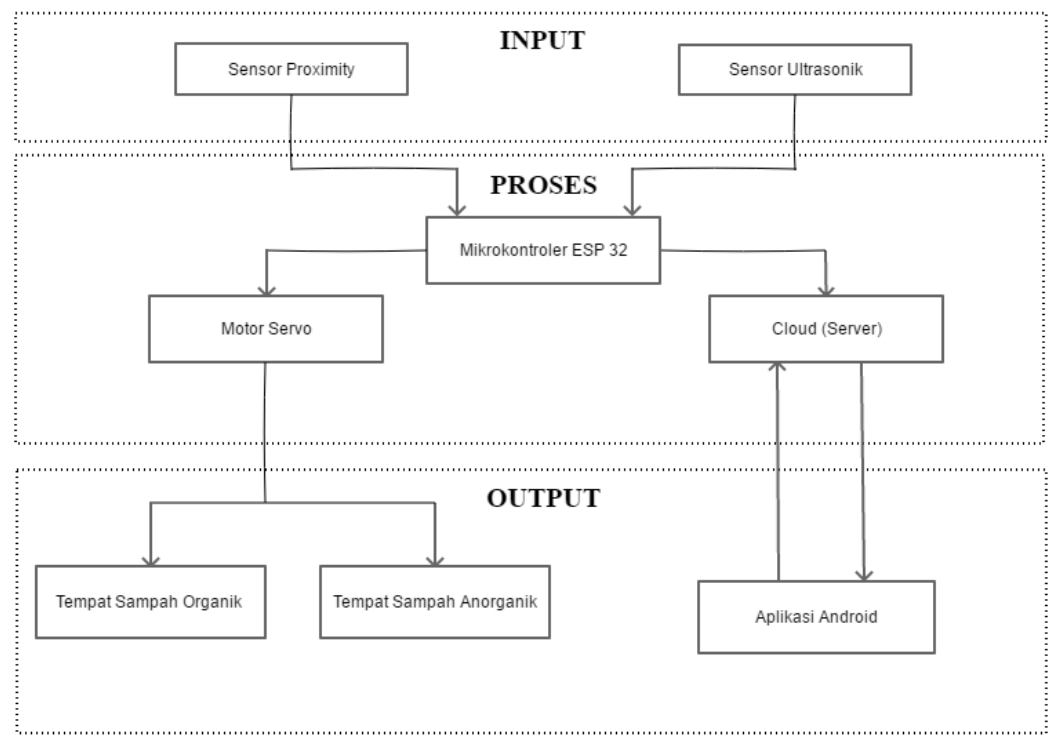

Gambar 6. Diagram Blok

\subsection{Diagram Alir}

Berikut adalah diagram alir dari alat yaitu sistem harus terkoneksi dengan internet supaya dapat bekerja. Jika sistem tidak terkoneksi maka sistem dari alat tidak akan bekerja

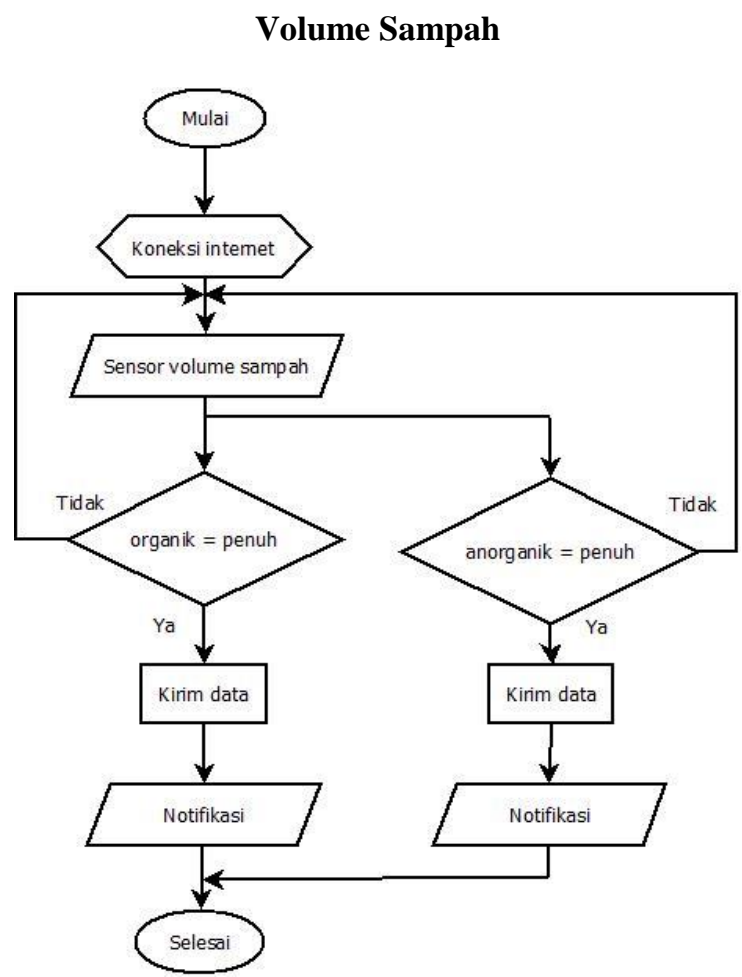

Gambar 7. Diagram Alir Volume Sampah 
Buka Tutup Tempat Sampah

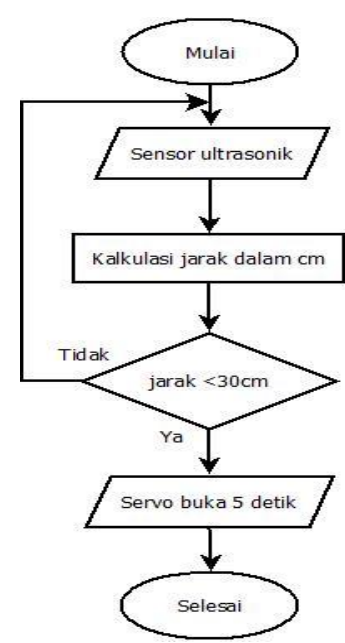

Gambar 8. Diagram Alir Buka Tutup Tempat Sampah
Pemilah Sampah

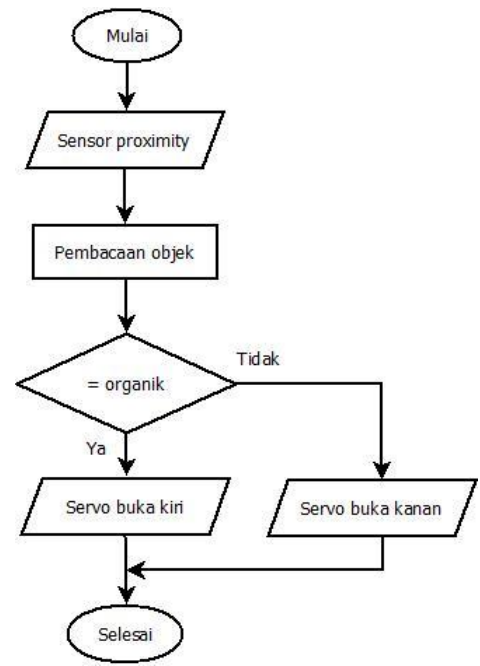

Gambar 9. Diagram Alir Pemilah Sampah

\subsection{Desain Alat}

Berikut merupakan desain alat dengan dimensi tinggi $50 \mathrm{~cm}$, panjang $40 \mathrm{~cm}$, lebar $20 \mathrm{~cm}$.

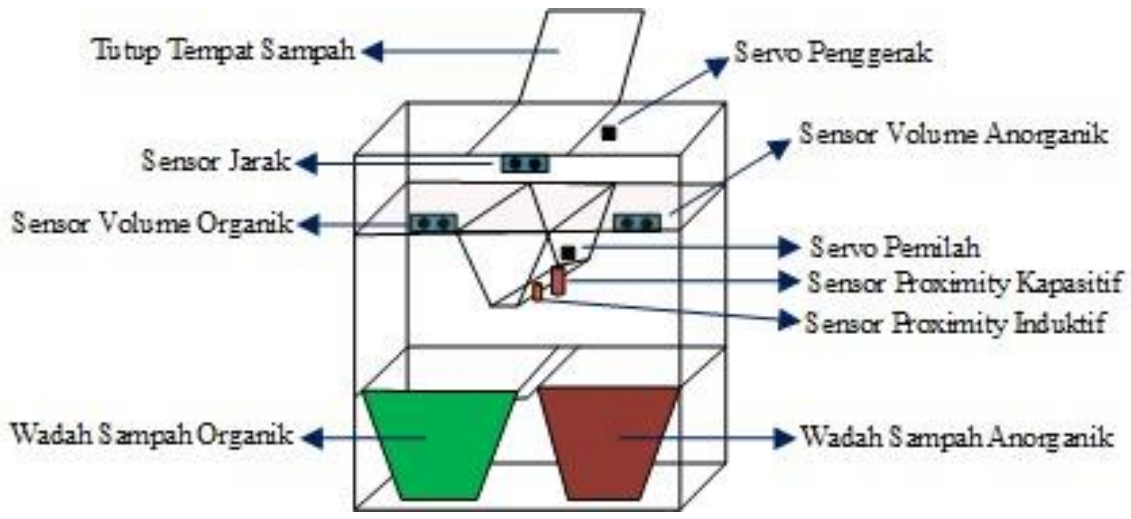

\subsection{Desain Aplikasi}

Gambar 10. Desain Alat

Berikut merupakan desain aplikasi untuk monitoring volume sampah.

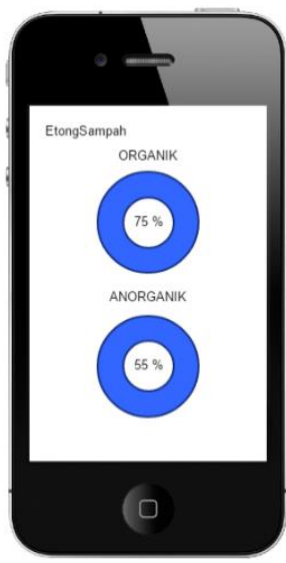

Gambar 11. Desain Aplikasi 


\section{HASIL DAN PEMBAHASAN}

\subsection{Pengujian Sensor Ultrasonik Buka Tutup Tempat Sampah}

Pengujian sensor ultrasonik buka tutup tempat sampah dilakukan dengan mengukur jarak antara sensor dengan objek yang kemudian akan dikombinasikan dengan servo untuk membuka tutup tempat sampah secara otomatis. Pada saat pengujian didapatkan hasil ketika objek berada pada jarak lebih dari $30 \mathrm{~cm}$ servo tidak akan bekerja. Jika sensor mendeteksi objek pada jarak kurang dari sama dengan $30 \mathrm{~cm}$ maka servo akan membuka.

\begin{tabular}{ccc}
\multicolumn{2}{c}{ Tabel 1 Pengujian Sensor Ultrasonik Buka Tutup Tempat Sampah } \\
\hline No & Pembacaan jarak $(\mathbf{c m})$ & Keadaan servo \\
\hline 1 & 100 & OFF $\left(0^{\circ}\right)$ Menutup \\
2 & 70 & OFF $\left(0^{\circ}\right)$ Menutup \\
3 & 50 & OFF $\left(0^{\circ}\right)$ Menutup \\
4 & 30 & ON $\left(90^{\circ}\right)$ Membuka \\
5 & 20 & ON $\left(90^{\circ}\right)$ Membuka \\
\hline
\end{tabular}

Tabel 2. Percobaan Deteksi Jarak Buka Tutup Tempat Sampah

\begin{tabular}{cccc}
\hline Percobaan & Jarak sebenarnya $(\mathbf{c m})$ & Jarak terdeteksi $(\mathbf{c m})$ & Error $(\%)$ \\
\hline 1 & 10 & 10,01 & 0,1 \\
2 & 12 & 12,04 & 0,33 \\
3 & 14 & 14,09 & 0,64 \\
4 & 16 & 16,13 & 0,8 \\
5 & 18 & 18,15 & 0,83 \\
6 & 20 & 20,14 & 0,7 \\
7 & 22 & 22,20 & 0,9 \\
8 & 24 & 24,22 & 0,91 \\
9 & 26 & 26,27 & 1 \\
10 & 28 & 28,35 & 1,25 \\
\hline \multicolumn{4}{c}{}
\end{tabular}

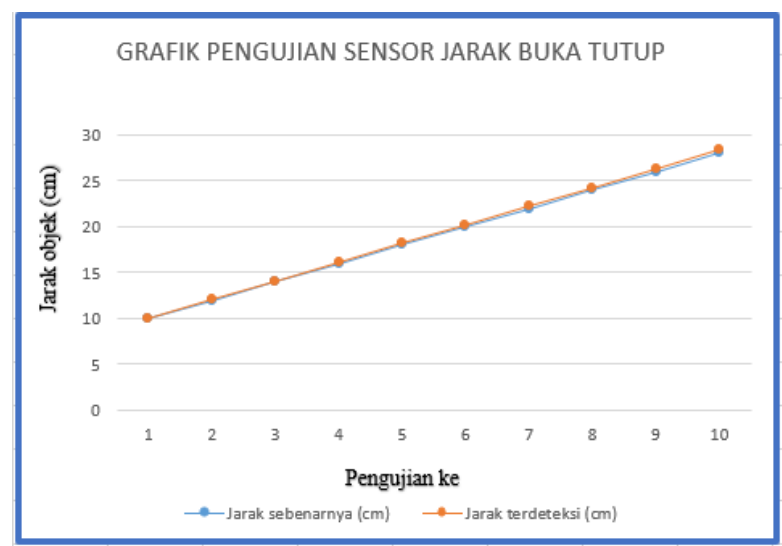

Gambar 12. Grafik Pengujian Sensor Jarak Buka Tutup

\subsection{Pengujian Sensor Ultrasonik Volume Sampah}

Pengujian sensor ultrasonik untuk volume sampah dilakukan untuk mengetahui seberapa besar error yang didapatkan ketika sensor mendeteksi adanya sampah pada tempat sampah. Pengujian dilakukan pada dua tempat yang berbeda yaitu tempat sampah organik dan anorganik. Pendeteksian volume sampah yaitu berdasarkan tinggi sampah yang ada pada tempat sampah. Sensor ultrasonik secara terus menerus memonitoring ketinggian sampah setiap saat. Ketika sampah telah mencapai titik ketinggian yang ditentukan maka sistem mengirimkan notifikasi. 
Tabel 3. Pengujian Sensor Ultrasonik Volume Sampah Organik

\begin{tabular}{cccc}
\hline Percobaan & Jarak sebenarnya $(\mathbf{c m})$ & Jarak terdeteksi $(\mathbf{c m})$ & Error $(\%)$ \\
\hline 1 & 30 & 30,39 & 1,3 \\
2 & 28 & 28,34 & 1,2 \\
3 & 26 & 26,30 & 1,15 \\
4 & 24 & 24,27 & 1,1 \\
5 & 22 & 22,24 & 1,09 \\
6 & 20 & 20,19 & 0,95 \\
7 & 18 & 18,17 & 0,94 \\
8 & 16 & 16,13 & 0,8 \\
9 & 14 & 14,09 & 0,64 \\
10 & 12 & 12,02 & 0,16 \\
\hline \multicolumn{4}{r}{}
\end{tabular}

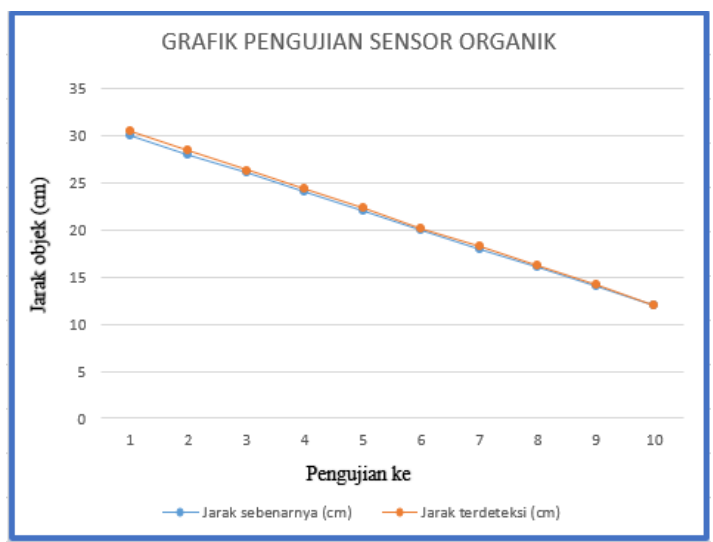

Gambar 13. Grafik Pengujian Sensor Organik

Tabel 4. Pengujian Sensor Ultrasonik Volume Sampah Anorganik

\begin{tabular}{cccc}
\hline Percobaan & Jarak sebenarnya $(\mathrm{cm})$ & Jarak terdeteksi $(\mathrm{cm})$ & Error $(\%)$ \\
\hline 1 & 30 & 30,41 & 1,36 \\
2 & 28 & 28,34 & 1,2 \\
3 & 26 & 26,29 & 1,1 \\
4 & 24 & 24,25 & 1 \\
5 & 22 & 22,19 & 0,86 \\
6 & 20 & 20,15 & 0,75 \\
7 & 18 & 18,13 & 0,72 \\
8 & 16 & 16,07 & 0,43 \\
9 & 14 & 14,04 & 0,28 \\
10 & 12 & 12,03 & 0,25 \\
\hline \multicolumn{5}{r}{} & & 0,79 \\
\hline
\end{tabular}




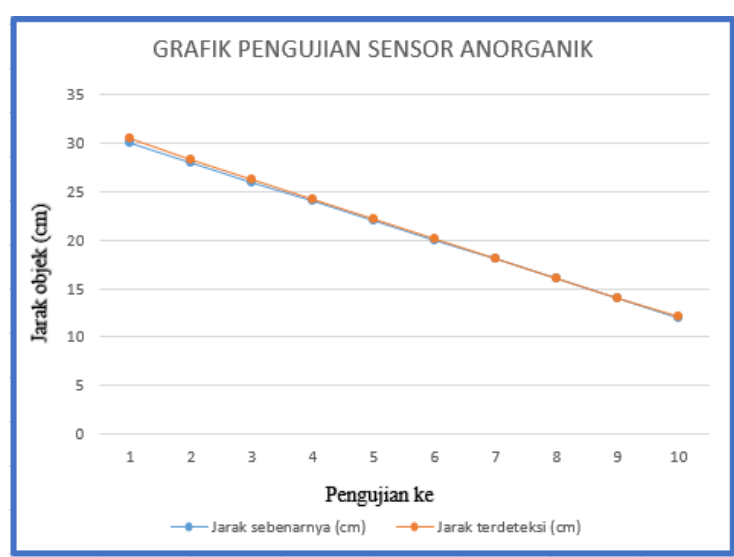

Gambar 14. Grafik Pengujian Sensor Anorganik

\subsection{Pengujian Sensor Proximity}

Pembacaan sensor proximity menggunakan sinyal digital dengan keluaran high-low (0/1). Pembacaan jenis sampah organik high atau bernilai logika 1. Sedangkan pembacaan jenis sampah anorganik low atau bernilai logika 0. Dari hasil pembacaan sensor proximity kapasitif dan induktif kemudian data yang diperoleh akan diproses dan selanjutnya servo pemilah akan menempatkan jenis sampah sesuai dengan tempatnya.

Tabel 5. Pengujian Sensor Proximity Pada Sampah Organik

\begin{tabular}{ccccc}
\hline No & Kayu & Daun & Kertas & Tissue \\
\hline 1 & 1 & 1 & 1 & 1 \\
2 & 1 & 1 & 0 & 1 \\
3 & 1 & 1 & 1 & 1 \\
4 & 1 & 1 & 1 & 0 \\
5 & 1 & 1 & 1 & 1 \\
6 & 1 & 1 & 1 & 1 \\
7 & 1 & 1 & 1 & 1 \\
8 & 1 & 1 & 1 & 1 \\
9 & 1 & 1 & 1 & 1 \\
10 & 1 & 1 & 1 & 1 \\
\hline Persentase & $100 \%$ & $100 \%$ & $90 \%$ & $90 \%$ \\
\hline
\end{tabular}

Tabel 6. Pengujian Sensor Proximity Pada Sampah Anorganik

\begin{tabular}{ccccc}
\hline No & Botol plastik & Plastik & Karet & Kaleng \\
\hline 1 & 0 & 0 & 0 & 0 \\
2 & 0 & 0 & 0 & 0 \\
3 & 0 & 0 & 0 & 0 \\
4 & 0 & 0 & 0 & 0 \\
5 & 0 & 0 & 0 & 0 \\
6 & 0 & 0 & 0 & 1 \\
7 & 0 & 0 & 0 & 0 \\
8 & 0 & 0 & 0 & 0 \\
9 & 0 & 0 & 0 & 0 \\
10 & 0 & 0 & 0 & 0 \\
\hline Persentase & $100 \%$ & $100 \%$ & $100 \%$ & $90 \%$ \\
\hline \multicolumn{2}{r}{} & 0 & &
\end{tabular}

\subsection{Persentase Keberhasilan Pemilah Organik dan Anorganik}

Setelah dilakukan percobaan dari setiap jenis sampah organik yaitu sampah kayu, sampah daun kering, sampah kertas dan sampah tissue sebanyak 10 kali didapatkan persentase keberhasilan sebesar 95\%. Pada jenis sampah anorganik dengan item sampah kaleng, botol plastik, plastik, karet, kaleng dilakukan sebanyak 10 kali didapatkan persentase keberhasilan rata-rata sebesar 97,5\%. 
Tabel 7. Persentase Keberhasilan Pemisah Organik Dan Anorganik

\begin{tabular}{ccccc}
\hline No & Kategori & Item sampah & Keberhasilan & Keberhasilan rata-rata \\
\hline \multirow{4}{*}{1} & \multirow{4}{*}{ Organik } & Kayu & $100 \%$ & \\
& & Daun & $100 \%$ & \multirow{2}{*}{$95 \%$} \\
& Kertas & $90 \%$ & \\
& & Tissue & $90 \%$ & \\
\multirow{2}{*}{2} & Anorganik & Botol Plastik & $100 \%$ & \multirow{2}{*}{ Plastik } \\
& & Karet & $100 \%$ & \\
& & Kaleng & $90 \%$ & \\
\hline
\end{tabular}

\subsection{Tampilan Aplikasi}

Tampilan aplikasi digunakan sebagai penampil volume sampah pada tempat sampah menggunakan android smartphone yang terhubung dengan internet. Perubahan ketinggian sampah akan termonitor dan ditampilkan secara real time pada aplikasi. Ketika volume sampah sudah mencapai ketinggian yang telah ditentukan maka android smartphone akan menerima notifikasi atau pemberitahuan bahwa tempah sampah telah penuh.

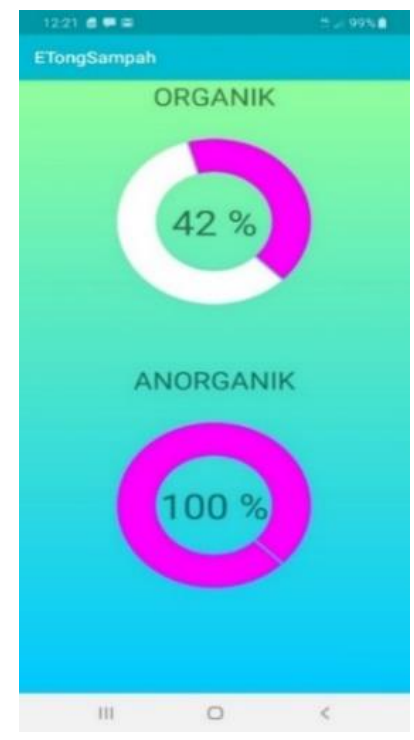

Gambar 15. Tampilan Aplikasi

\section{KESIMPULAN}

1. Sistem otomatisasi tempat sampah menggunakan mikrokontroler ESP 32 berdasarkan hasil pengujian dapat membedakan anatara sampah organik maupun sampah anorganik. Kondisi tempat sampah dapat termonitoring dan mengirimkan status tempat sampah ke server secara realtime.

2. Sensor ultrasonik HCSR04 digunakan sebagai pendeteksi jika ada aktivitas manusia ingin membuang sampah dan mendeteksi ketinggian sampah dapat berfungsi secara normal dengan memberikan keterangan berupa persentase volume tempat sampah. Berdasarkan hasil pengujian pembacaan volume tempat sampah didapatkan keberhasilan pada sensor buka tutup sebesar 99,26\%, sensor organik sebesar 99,07\% dan sensor anorganik sebesar 99,21\%.

3. Untuk memilah sampah organik dan sampah anorganik menggunakan sensor proximity kapasitif sebagai pendeteksi sampah organik dan sensor proximity induktif sebagai pendeteksi sampah anorganik. Berdasarkan hasil pengujian pembacaan objek sampah didapatkan keberhasilan pada sampah organik 95\% dan sampah anorganik sebesar $97,5 \%$. 
4. Tempat sampah ini menggunakan sistem informasi berbasis Internet Of Things (IOT) ynag terhubung pada aplikasi android smartphone. Aplikasi dapat memonitoring kondisi tempat sampah berdasarkan data yang tersimpan pada server dan menerima notifikasi ketika tempat sampah telah penuh.

\section{REFERENSI}

[1] Sukarjadi., Arifiyanto., Tobagus, D., 2017, Perancangan dan Pembuatan Smart Trash Bin Berbasis Arduino Uno di Universitas Maarif Hasyim Latif, Engineering and Sains Journal, Politeknik Sakti Surabaya, Surabaya.

[2] Wuryanto, A., Hidayatun, N., Rosmiati, M., 2019, Perancangan Sistem Tempat Sampah Pintar Dengan Sensor HCRSF04 Berbasis Arduino UNO R3, Jurnal Komputer dan Informatika Universitas Bina Sarana Informatika, Universitas Bina Sarana Informatika, Yogyakarta.

[3] Pratama, H., Haritman, E., Gunawan, T., 2012, Akuisisi Data Kinerja Sensor Ultrasonik Berbasis Sistem Komunikasi Serial Menggunakan Mikrokontroler Atmega 32, Journal Electrans, FPTK UPI, Bandung.

[4] Suhaeb, S., Djawad, Y., Jaya, H., 2017, Mikrokontroler dan Interface, Universitas Negeri Makasar, Makasar.

[5] Tholib, R., Nurkhamid., 2017 , Automatic Warning System Smarttrash (AWASSH) Berbasis Arduino Nano, E-Jurnal Prodi Teknik Elektronika dan Informatika Edisi Proyek Akhir D3, Universitas Negeri Yogyakarta, Yogyakarta..

[6] William., Kristanto, K., Hartanto, T., 2019, Rancang Bangun Tempat Sampah Pintar Menggunakan Algoritma Fuzzy Logic Berbasis Arduino, Journal of Informatics and Telecommunication Engineering, FTIK Universitas Prima Indonesia, Indonesia

\section{BIOGRAFI PENULIS}

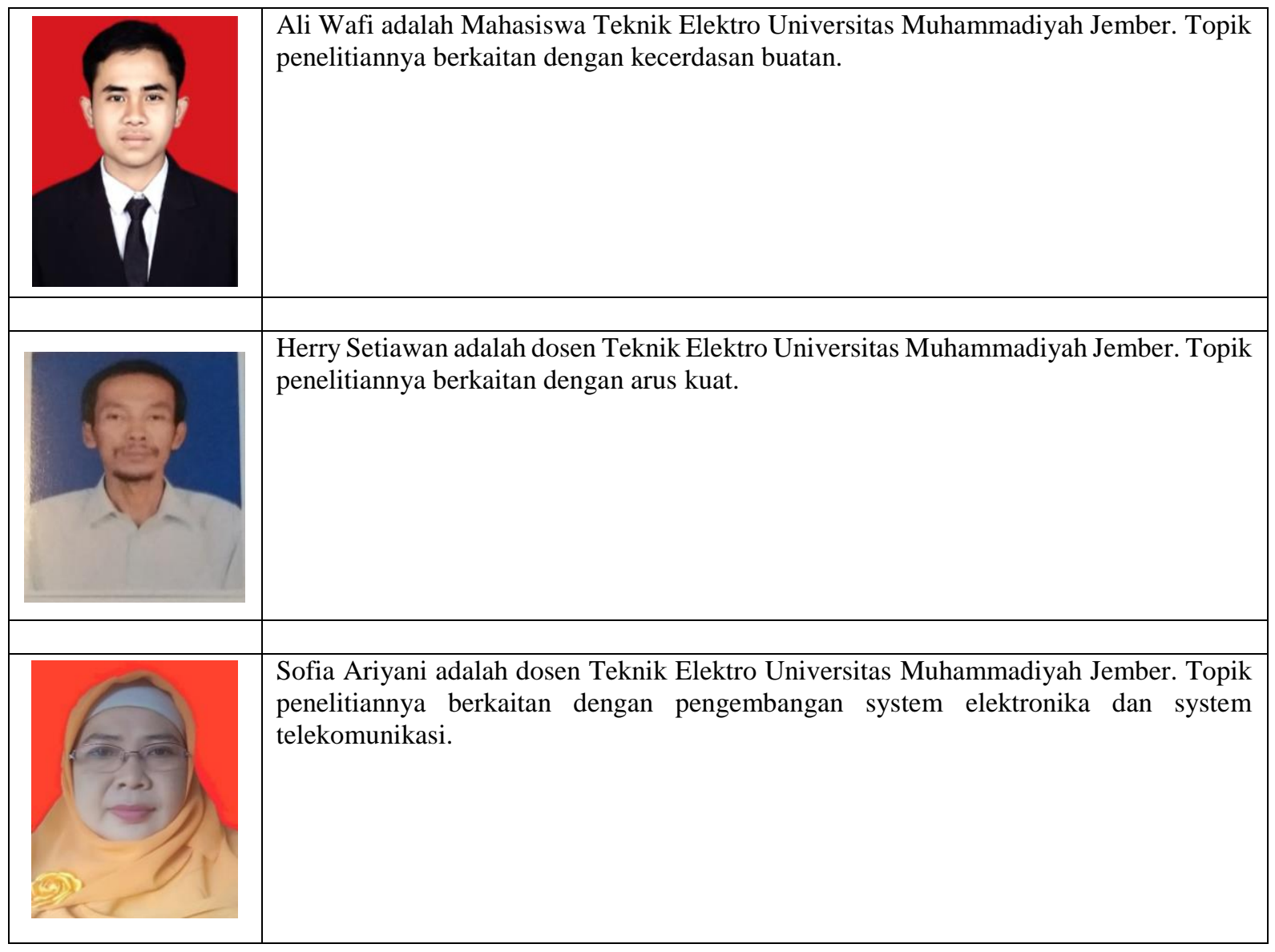

